\title{
PENGELOLAAN DANA DESA
}

\author{
Henry Agus Sulistiono \\ Universitas Islam Nahdlatul Ulama Jepara \\ Prodi Perbankan Syariah, dan Prodi Akuntansi ${ }^{2,3}$ Fakultas Ekonomi dan Bisnis \\ henryagussulistiyono@gmail. \\ Dwi Erlin Effendi \\ Universitas Islam Nahdlatul Ulama Jepara \\ Fakultas Ekonomi dan Bisnis \\ erlin.effendi@gmail.com \\ Jumaiyah \\ Universitas Islam Nahdlatul Ulama Jepara \\ Fakultas Ekonomi dan Bisnis \\ mayawahidah@unisnu.ac.id
}

\begin{abstract}
The long-term objective of this study is to find a model of assistance for village officials in compiling village financial reports in accordance with Permendagri No. 113 of 2014. In the short term, this study wants to find out how the village apparatus in preparing financial statements and what are the constraints in preparing financial statements Village. The method used in this study is to use descriptive quantitative research by collecting financial statement data in 2016 and then analyzed where this financial report will be sought in accordance with Permendagri No. 113 of 2014. The results of this study are the sengonbugel village government has organized a government with use the Village funds budget in accordance with the Permendagri number 113 of 2014. It's just that in the field of administration of the Village administration there is an allowance for the family which has not been regulated in the Permendagri.
\end{abstract}

Keywords: financial report, Village Government, Permengari number 113 of 2014

Ringkasan

Tujuan jangka panjang penelitian ini untuk menemukan model pendampingan bagi aparatur Desa dalam menyusun laporan keuangan Desa sesuai dengan Permendagri no 113 Tahun 2014. Dalam waktu jangka pendek penelitian ini ingin mengetahui bagaimana aparatur Desa dalam menyusun laporan Keuangan serta apa saja yang menjadi kendala dalam penyusunan laporan keuangan Desa. Metode yang digunakan dalam penelitian ini yaitu dengan menggunakan penelitian kuantitatif diskriftif dengan cara mengumpilkan data laporan keuangan pada tahun 2016 kemudia dianalisis dimana laporan keuangan ini akan di cari kesesuaian dengan permendagri No 113 Tahun 2014. Hasil dalam penelitian ini adalah pemerintah Desa sengonbugel sudah menyelenggarakan pemerintahan dengan menggunakan anggaran dana Desa sesuai dengan permendagri nomor 113 Tahun 2014. Hanya saja pada akun bidang penyelengaraan pemerintahan Desa ada tunjangan untuk keluarga yang mana belum di atur dalam permendagri tersebut.

Kata Kunci : laporan keuangan, Pemerintah Desa, Permengari nomor 113 Tahun 2014 


\section{PENDAHULUAN}

Desa merupakan tolak ukur kemandirian dan kemajuan bangsa, jika sebuah negara Desanya maju maka majulah bangsa tersebut. Jika Desa merupakan tempat ketahanan pangan maka negarapun tidak akan merasakan kelaparan. Filosofi inilah yang melahirkan Undang-Undang Tentang Desa terbit pada tahun $2014^{[1]}$ yaitu Undang-Undang Nomor 6 Tahun 2014 tentang Desa. Pada Bab III tentang keuangan Desa dan Aset Desa pasal 72 pointer $b$ di sebutkan pendapatan Desa bersumber dari alokasi Anggaran Pendapatan dan Belanja Negara. Kemudian diatur oleh Negara setiap Desa mendapatkan 1 (satu ) Milyar. Implikasi dari kebijakan ini bukan berarti tidak berdampak baik dampak positif maupun negatif, dampak positif bagi Desa, Desa mampu memajukan Desanya dengan memperbaiki infrastruktur yang rusak atau yang perlu diadakan, Desa juga dapat memberdayakan masyarakat Desa dengan produk unggulan yang dimiliki Desa bersangkutan .

Namun demikian dampak negatif dari anggaran Dana Desa yang cukup besar tersebut banyak dialami Desa-Desa yang ada, terutama Desa yang belum mempunyai Sumberdaya Manusia yang andal untuk melaporkan Anggaran Dana Desa (ADD) dengan baik. Sebagaimana hasil penelitian yang di lakukan oleh Hanifah\& praptoyo (2015) menunjukkan pelaksanaan yang akuntabel dan transparan yang dilihat dari pelaporan pertangungjawaban Anggaran Pendapatan Belanja Desa (APBDesa), namun dari sisi pencatatan akuntansi masih diperlukan adanya pembinaan dan pelatihan lebih lanjut, karena belum sepenuhnya sesuai dengan ketentuan. Hambatan utamanya adalah belum efektifnya pelatihan para perangkat desa dan kompetensi sumber daya manusia, sehingga masih memerlukan perhatian khusus dari aparat pemerintah desa secara berkelanjutan.Sementara itu penelitian Ismaildkk (2016) menunjukkan bahwa permasalahan utama yang timbul adalah rendahnya pengetahuan dari kepala desa terkait pengelolaan keuangan desa berdasarkan Permendagri No. 113/2014.Pelaksanaan pelaporan keuangan Desa sesuai dengan permendagri nomor 113 Tahun 2014 masih jauh dari harapan hal ini diuangkapkan oleh Wahyuni (2016) Perbandingan kesesuaian pelaksanaan keuangan di desa Rowogempol pada Peraturan Dalam Negeri No.113 Tahun 2014 adalah sebesar 85\% dimana ada sedikit tidak kesesuaian pelaksanaan 
keuangan didesa Rowogempol. Ketidak sesuaian laporan penggunaan anggaran di Desa yang mempunyai Sumberdaya Manusia masih kurang $15 \%$ apalagi bagi Desa di mana perangkatnya Desanya secara kualitas sumberdaya manusia jauh dari harapan seperti yang terjadi di Desa Sengon bungle Jepara Suara Merdeka.Com (15 Oktober 2016) petinggi Desa sengon bugel diberhentikan dari jabatanya lantaran berbagai kasus pelaporan keuangan yang belum di selesaikan salah satu laporan keuangan tersebut adalah laporan penggunaan Anggaran Dana Desa (ADD).

Perbedaan penelitian ini dengan penelitian sebelunya adalah penelitian ini lebih focus pada bagaimana penyusunan laporan keuanganya penggunaan anggaran dana desa tahun 2016 setelah ada pergantian petinggi Desa. Penelitian ini menjadi sangat penting sekali dilakukan karna petinggi sebelumnya melanggar permendagri nomor 113 Tahun 2014sehingga untuk membandingkan laporan keuangan sebelum ada pergantian petinggi Desa Sengon Bugel dan setelah ada pergantian petinggi desa Sengon Bungel.

Sejak tahun 2015 Desa di percaya oleh pemerintah untuk mengolah danaya sendiri yang di ambilkan dari anggaran Pendapatan Negara (APBN) dengan tujuan untuk mensejahtrakan masyarakat Desa, seperti tujuan pembangunan Desa menurut UU No. 6 Tahun 2014adalah untuk meningkatkan kesejahtraan masyarakat Desa dan kualitas hidup manusia, serta penanggulangan kemiskinan melalui penyediaan pemenuhan kebutuhan dasar, pembangunan sarana dan prasarana, pengembangan potensi ekonomi lokal, serta pemanfaatan sumberdaya alam dan lingkungan secara berkelanjutan.

Konsekkuensi dari UU tersebut Desa harus mampu mengolah keuangan dan melaporkan keuangan sesuai dengan ketentuan yang berlaku yang tertuang dalam permendagri No 113 Tahun 2014 tentang pengelolaan keuangan Desa. Akan tetapi banyak Desa yang belum mampu mengolah Dananya sesuai dengan Permendagri No 113 Tahun 2014 sebagaimana penelitiaan yang di lakukan oleh Muhammad dkk (2016) permasalahan utama yang timbul dalam mengelola keuangan Desa adalah rendahnya pengetahuan dari kepala desa terkait pengelolaan keuangan desa berdasarkan Permendagri No. 113/2014 Terkait dengan pelaporan pengelolaan keuangan Desa banyak sekali desa yang masih membutuhkan 
bimbingan dalam pembuatan laporan. Suci dan sugeng (2015)dalam pelaporan keuangan Desa terutama pencatatan akuntansi masih diperlukan adanya pembinaan dan pelatihan lebih lanjut, karena belum sepenuhnya sesuai dengan ketentuan. Adapun laporan yang harus disiapkan oleh desa menurut permendagi 113 Tahun 2014 adalah buku kas umum, buku kas pembantu pajak, buku bank, laporan realisasi APBDes, laporan kekayaan milik Desa.Kas Bultek 14 (2014)menjelaskan Kas merupakan aset pemerintah paling lancar (likuid) dan aktif, dalam hal keuangan desa merupakan asset pemerintah Desa. Sementara buku kas umum adalah buku yang disediakan untuk mencatat semua transaksi penerimaan dan pengeluaran kas baik ssecara tunai maupun giral, mutasi kas dari bank ke tunai dan perbaikan/ koreksi kesalahan pembukuan.Sutiono, Pusdiklat Akuntansi Pemerinta (2015) Buku kas pembantu pajak digunakan untuk mencatat bukti transaksi terkait dengan pemungutan maupun penyetoran pajak oleh bendahara desa. Buku bank digunakan untuk

mencatat bukti transaksi terkait dengan penerimaan maupun pengeluaran melalui bank. Berikut ini simulasi yang tidak menggunakan data yang
sebenarnya.Akuntabilitas sudah merupakan mandat bagi eksekutif sebagai pelaksana kegiatan pemerintahan untuk mengungkapkan semua aktifitas yang dilaksanakan. Mahmudi (2010:23)mengatakan akuntabilitas adalah "Kewajiban agen (pemerintah) untuk mengelola sumber daya, melaporkan, dan mengungkapkan segala aktivitas dan kegiatan yang berkaitan dengan penggunaan sumber daya publik kepada pemberi mandat (prinsipal)".

\section{METODE PENELITIAN}

Metode yang digunakan dalam penelitian ini yaitu dengan menggunakan penelitian kuantitatif diskritif, dengan mengumpulkan data laporan keuangan pada tahun 2016 dimana laporan keuangan ini akan di cari kesesuaian dengan permendagri No 113 Tahun 2014 .

Data yang akan diolah dalam penelitian ini adalah data laporan keuangan Desa Sengon Bungel tahun Kac. MayongKab.Jepara. Dokumentasi akan diambil guna melengkapi data penelitian seperti dokumentasilaporan keuangan tahunan. 


\section{HASIL PENELITIAN}

Berdasarkan data yang diperoleh dari Desa melalui perangkat Desa. Desa mengeluarkan peraturan nomor 1 tahun 2017 tentang laporan pertaggungjawaban realisasi pelaksanaan anggaran pendapatan dan belanja desa tahun anggaran 2016 .peraturan ini ditandatangani pada tanggal 7 januari 2017. Peraturan tersebut kemudian dijabarkan dalam laporan

\section{LAPORAN PERTANGGUNGJAWABAN REALISASI PELAKSANAAN APBDes} PEMERINTAH DESA SENGONBUGELTAHUN ANGGARAN 2016

Table 1.1 Laporan Realisasi Anggaran Dana Desa Ajun Pendapatan

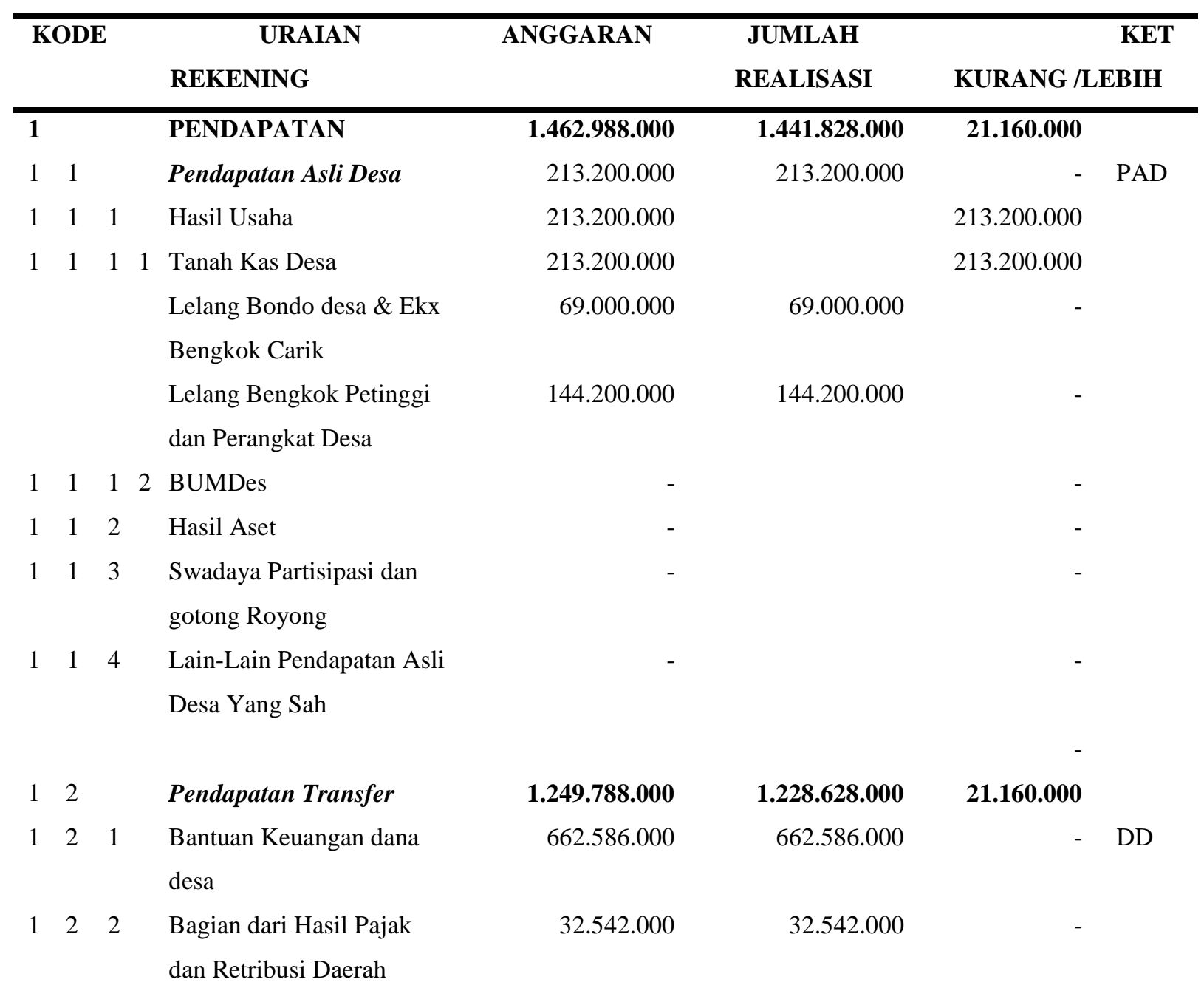


Kabupaten/Kota

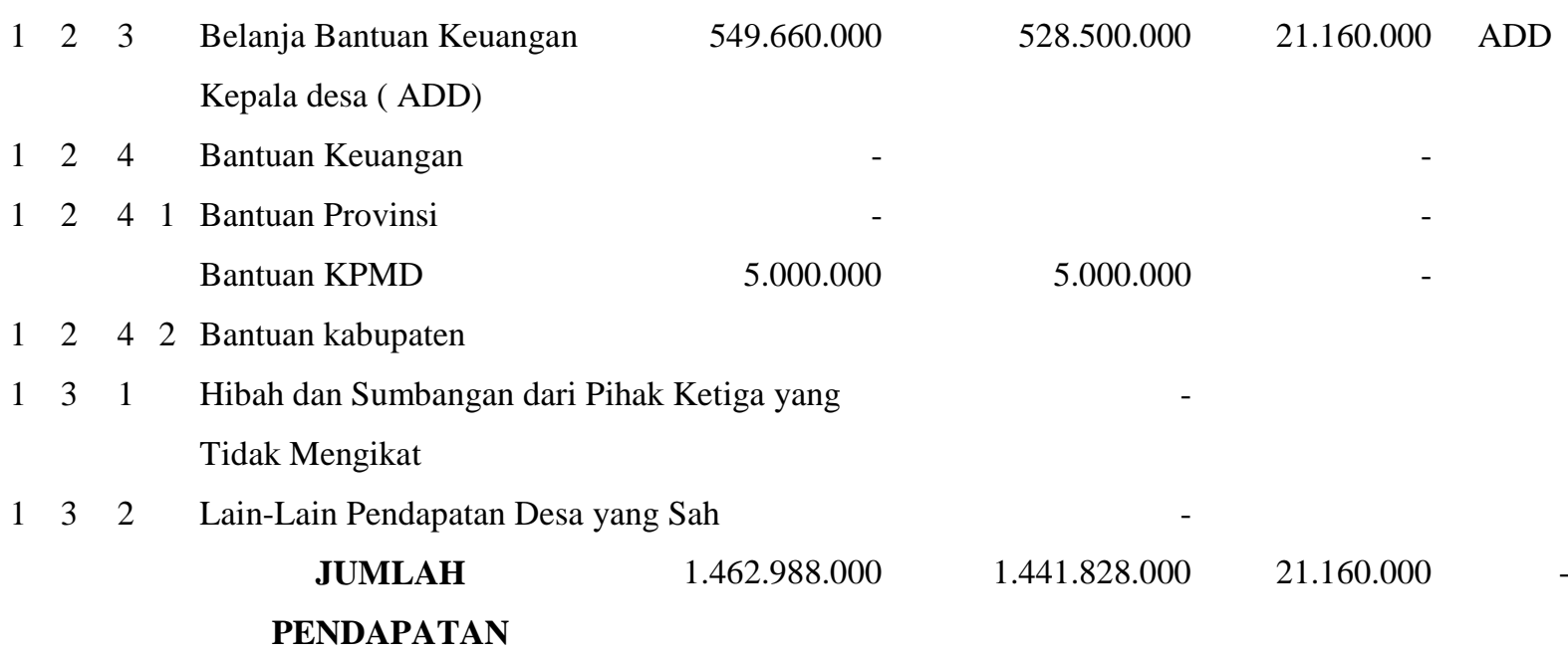

2

21

\section{BELANJA}

Bidang Penyelenggaraan

Pemerintahan Desa

$\begin{array}{llll}2 & 1 & 1 & \text { Penghasilan Tetap dan }\end{array}$

Tunjangan

$\begin{array}{llll}2 & 1 & 1 & \text { Belanja Pegawai }\end{array}$

$\begin{array}{lllll}2 & 1 & 1 & 1 & \text { Penghasilan Tetap petinggi }\end{array}$

dan Perangkat Desa

$\begin{array}{lllll}2 & 1 & 1 & 2 & \text { Tunjangan Kepala Desa }\end{array}$

dan Perangkat Desa

Tunjangan Kesehatan Petinggi dan Perangkat

Tunjangan istri /suami dan

anak petinggi dan

perangkat

tambahan tunjangan bagi

petinggi dan perangkat

tambahan tunjangan carik

dari bengkoknya

tunjangan assuransi jiwa

dan PA bagi petinggi dan

perangkat

$\begin{array}{lllll}2 & 1 & 1 & 3 & \text { Tunjangan Para Anggota BPD }\end{array}$

212 Operasional Perkantoran

212 Belanja Barang dan Jasa

$\begin{array}{lllll}2 & 1 & 2 & 1 & \text { Alat Tulis Kantor }\end{array}$
144.200 .000

11.200 .000

15.545 .000

25.200 .000

45.385.000

\subsubsection{0 \\ 474.500.000}

386.075 .000

386.075 .000

179.400 .000

10.530 .000

1.441.828.000

453.340.000

364.915 .000

364.915.000

167.900 .000

21.160 .000

11.500.000 ADD

39.535.000

3.500 .000
10.530 .000

144.200.000

- ADD

21.160.000

21.160 .000

11.200 .000

- PAD

13.085 .000

2.460 .000

ADD

18.000 .000

7.200.000

ADD

- ADD

45.385.000

- ADD

39.535 .000

- ADD

3.500 .000

- ADD
21.160.000 
2122 Benda Pos

Bahan /Material

Pemeliharaan dan

Peralatan Mesian

2123 Cetak dan Penggandaan

Air, Listrik, dan Telepon

Peralatan Kebersihan

danPembersih

Makanan dan Minuman

Rapat

Rekening Listrik dan Pulsa

Perjalanan Dinas / Uang

saku

Langganan Surat Kabar

dan Majalah

Belanja Jasa Perpanjangan

STNK

Belanja Perawatan dan

Kendaraan Bermotor

Honor Pengelola PTPKD

$\begin{array}{lllll}2 & 1 & 2 & 3 & \text { Belanja Modal }\end{array}$

Pengadaan Leptop dan

komputer

$\begin{array}{llll}2 & 1 & 3 & \text { Operasional BPD }\end{array}$

$213 \quad 2$ Belanja Barang dan Jasa

ATK

Penggadaan

Konsumsi Rapat

Benda Pos

$\begin{array}{llll}2 & 1 & 4 & \text { Operasional Rt/Rw }\end{array}$

Belanja Barang dan Jasa

23.900.000

Honorarium / Operasional Pengurus Rt

Ketua 17 Rt x 600000

Sekretaris 17 Rt x 400000

Bendahara 17 Rt 300000

Honor ketua Rt / Rw 3 Rw

x 600000

215 Penunjang Kegiatan

16.140 .000
10.200 .000

6.800 .000

5.100 .000

1.800 .000

\author{
510.000 \\ 2.000 .000 \\ 1.000 .000
}

600.000

500.000

500.000

5.500 .000

600.000

1.200 .000

225.000

2.500 .000

1.500 .000

18.600 .000

5.850 .000

3.000.000

3.000 .000

1.083 .500

62.500

1.800 .000

54.000

$$
510.000
$$$$
2.000 .000
$$$$
1.000 .000
$$

600.000

500.000

500.000

5.500 .000

- ADD

600.000

1.200 .000

- ADD

- ADD

225.000

- ADD

2.500 .000

- ADD

1.500 .000

- ADD

18.600 .000

- ADD

- ADD

5.850 .000

- ADD

3.000.000

3.000 .000

1.083 .500

62.500

1.800 .000

54.000

23.900.000

- PAD

- PAD

- ADD

- ADD

- ADD

- ADD

- ADD

- ADD

- ADD

ADD

ADD

ADD

ADD

ADD 
Penyelenggaraan

Pemerintah

2151 Penunjang Kegiatan

6.000 .000

6.000 .000

- $\mathrm{ADD}$

Penyusunan

RKPDes/RKA/APBDes/D

PA/LPPD/LKPPD

$2 \quad 1 \quad 6 \quad 1$ Penunjang Kegiatan

1.000 .000

1.000 .000

$-\quad$ ADD

Pelatihan PTPKD

$\begin{array}{lllll}2 & 1 & 6 & 2 & \text { Belanja Barang dan jasa }\end{array}$

5.540 .000

5.540 .000

- $\mathrm{ADD}$

2

Spanduk

450.000

450.000

- ADD

ATK dan Biaya Pelaporan

500.000

500.000

- ADD

Konsumsi

Snak

540.000

540.000

- ADD

Makan

Minuman Tambahan

1.200 .000

1.200 .000

- ADD

350.000

350.000

- ADD

Uang saku Musrenbangdes

- ADD

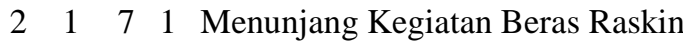

$\begin{array}{lllll}2 & 1 & 7 & 1 & \text { Belanja Barang dan Jasa }\end{array}$

2

Operasional Pembagian

raskin 36 Ok x 100000

22

Bidang Pelaksanaan

Pembangunan Desa

$\begin{array}{llll}2 & 2 & 1 & \text { Pembangunan Rabat Beton }\end{array}$

Rt.01 s/d 03 /Rw.002

222 Pembangunan Rabat Beton Rt.04 s/d 02 /Rw.002

223 Pembangunan Rabat Beton Rt.01 Rw.001

$2 \quad 24$ Pembangunan Rabat Beton Rt.01 Rw.003

525 Pembangunan Rabat Beton
2.500 .000

2.500 .000

3.600 .000

3.600 .000

$-\quad \mathrm{ADD}$
897.738.000

400.000 .000

4.000 .000

250.000 .000

6.000 .000

92.175 .000

25.000 .000

20.000 .000

16.800 .000

897.738.000

20.000 .000

16.800 .000
- ADD

- ADD

- ADD

- $\mathrm{ADD}$

- ADD

- $\mathrm{ADD}$

- ADD

- ADD
25.000 .000

- ADD

- $\mathrm{ADD}$

00.000

92.175 .000

- $\mathrm{ADD}$

- ADD 


\section{Rt.01 Rw.000}

\begin{tabular}{|c|c|c|c|c|}
\hline & 2 & 6 & & $\begin{array}{l}\text { PembangunanSaluran air } \\
\text { Rt.01 Rw.003 }\end{array}$ \\
\hline & 2 & 7 & 1 & $\begin{array}{l}\text { PembangunanSaluran air } \\
\text { Rt.07 Rw.002 }\end{array}$ \\
\hline & 2 & 8 & 2 & $\begin{array}{l}\text { Bantuan TK GUPPI Rt/Rw } \\
007 / 003\end{array}$ \\
\hline & 2 & 9 & & $\begin{array}{l}\text { Bantuan TPQ SIDROTUL } \\
\text { MUNTAHA }\end{array}$ \\
\hline & 2 & \# & & $\begin{array}{l}\text { Pembangunan Kantor BPD } \\
\text { dan PKK }\end{array}$ \\
\hline
\end{tabular}

11.000 .000

11.000 .000

- ADD

$$
12.586 .000
$$$$
12.586 .000
$$$$
\text { - ADD }
$$

$$
5.000 .000
$$$$
5.000 .000
$$$$
\text { - } \mathrm{ADD}
$$$$
7.500 .000
$$$$
7.500 .000
$$$$
\text { - } \mathrm{ADD}
$$

32.542 .000

- $\mathrm{ADD}$

\subsubsection{0} Kemsyarakatan

$\begin{array}{llll}2 & 3 & 1 & \text { Penunjang Kegiatan PKK }\end{array}$

7.000 .000

7.000 .000

- $\mathrm{ADD}$ Desa

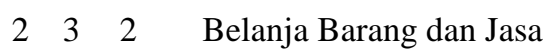

$2 \quad 3 \quad 3$ Penunjang Kegiatan BBRGM
$\begin{array}{llll}2 & 3 & 4 & \text { Penunjang Kegiatan }\end{array}$ LINMAS

235 Penunjang Kegiatan

5.000 .000

5.000 .000

- ADD GNOTA

$\begin{array}{llll}2 & 3 & 6 & \text { Penunjang Kegiatan PMI }\end{array}$

450.000

450.000

- ADD

$\begin{array}{llll}2 & 3 & 7 & \text { Penunjang kegiatan POS }\end{array}$

PAUD

$$
\begin{array}{r}
300.000 \\
4.500 .000
\end{array}
$$

300.000

4.500 .000

- ADD

- ADD

24

Bidang Pemberdayaan

67.500.000

\subsubsection{0}

\section{Masyarakat}

$\begin{array}{llll}2 & 4 & 1 & \text { Penunjang Kegiatan }\end{array}$

8.400 .000

8.400 .000

- ADD

Posyandu, Polindes, pusling desa dan posyandu lansia

242 Penunjang KegiatanBKB

243 Penunjang Kegiatan

3.500 .000

600.000

3.500 .000

- $\mathrm{ADD}$

PPKBD

244 Penunjang Kegiatan

Promosi Potensi Desa 


\begin{tabular}{|c|c|c|c|c|c|c|c|}
\hline \multirow{3}{*}{\multicolumn{2}{|c|}{24}} & \multirow[t]{3}{*}{5} & \multirow{3}{*}{$\begin{array}{l}\text { Penunjang Kegiatan } \\
\text { Pelestarian Budaya/ } \\
\text { Sedekah Bumi }\end{array}$} & \multirow[t]{3}{*}{15.000 .000} & \multirow[t]{3}{*}{15.000 .000} & \multirow[t]{3}{*}{ - } & \multirow[t]{3}{*}{ ADD } \\
\hline & & & & & & & \\
\hline & & & & & & & \\
\hline \multirow[t]{2}{*}{2} & 4 & 6 & Penunjang Kegiatan & 5.000 .000 & 5.000 .000 & - & $\mathrm{ADD}$ \\
\hline & & & Operasional KPMD & & & & \\
\hline \multirow[t]{2}{*}{2} & 4 & 7 & Menunjang Kegiatan & 2.000 .000 & 2.000 .000 & - & $\mathrm{ADD}$ \\
\hline & & & UPPKS & & & & \\
\hline \multirow[t]{3}{*}{2} & 4 & 8 & Menunjang Kegiatan & 10.000 .000 & 10.000 .000 & - & $\mathrm{ADD}$ \\
\hline & & & Lomba-Lomba dan & & & & \\
\hline & & & Kreatifitas Warga & & & & \\
\hline 2 & 4 & 9 & Penunjang Kegiatan P3AT & 5.000 .000 & 5.000 .000 & - & $\mathrm{ADD}$ \\
\hline \multirow[t]{2}{*}{2} & 4 & $\#$ & Menunjang Kegiatan & 5.000 .000 & 5.000 .000 & - & $\mathrm{ADD}$ \\
\hline & & & LKMD & & & & \\
\hline \multirow[t]{3}{*}{2} & 4 & $\#$ & Menunjang Kegiatan & 3.000 .000 & 3.000 .000 & - & $\mathrm{ADD}$ \\
\hline & & & BUMDES & & & & \\
\hline & & & & & & - & $\mathrm{ADD}$ \\
\hline 2 & 5 & & Bidang Tak Terduga & 3.000 .000 & 3.000 .000 & - & $\mathrm{ADD}$ \\
\hline \multirow[t]{5}{*}{2} & 5 & 1 & Menunjang Kegiatan & 3.000 .000 & 3.000 .000 & - & $\mathrm{ADD}$ \\
\hline & & & Penanganan Bencana alam & & & & \\
\hline & & & dan Penanganan Pengungsi & & & & \\
\hline & & & JUMLAH BELANJA & 1.462 .988 .000 & 1.441 .828 .000 & 21.160 .000 & $\mathrm{ADD}$ \\
\hline & & & SURPLUS/DEFISIT & 21.160 .000 & & 21.160 .000 & $\mathrm{ADD}$ \\
\hline 3 & & & PEMBIAYAAN & & & & \\
\hline 3 & 1 & & Penerimaan Pembiayaan & 21.160 .000 & & 21.160 .000 & $\mathrm{ADD}$ \\
\hline 3 & 1 & 1 & SiLPA 2016 & 21.160 .000 & & 21.160 .000 & $\mathrm{ADD}$ \\
\hline 3 & 1 & 2 & Pencairan Dana Cadangan & & & & \\
\hline \multirow[t]{2}{*}{3} & 1 & 3 & Hasil Kekayaan Desa yang Dipi & sahkan & & & \\
\hline & & & JUMLAH & 21.160 .000 & & 21.160 .000 & $\mathrm{ADD}$ \\
\hline 3 & 2 & & Pengeluaran Pembiayaan & 21.160 .000 & & -21.160 .000 & $\mathrm{ADD}$ \\
\hline 3 & 2 & 1 & Pembentukan Dana Cadangan & & & - & $\mathrm{ADD}$ \\
\hline 3 & 2 & 2 & Penyertaan Modal Desa & & & - & $\mathrm{ADD}$ \\
\hline & & & JUMLAH & - $\quad 21.160 .000$ & & -21.160 .000 & $\mathrm{ADD}$ \\
\hline
\end{tabular}


Apabila disandingkan dengan permendagri nomor 113 Tahun 2014 ${ }^{[8]}$ maka akun pendapatan asli Desa sudah sesuai, hanya saja kolom pendapatan lain-lain belum di pisahkan dengan pendapatan utama Desa.Sebagaimana pasal 9 pendapatan asli Desa terdiri dari Pendapatan Asli Desa (PADesa), Transfer dan Pendapatan Lain-Lain. Dijelaskan lebih lanjut bahwa pendapatan Desa kelompok PADesa terdiri atas jenis:Hasil usaha, Hasil asset, Swadaya, partisipasi dan Gotong royongserta lain-lain pendapatan asli desa. Dalam permendagri tersebut yang di maksud dengan PAD bisa di peroleh dari hasil BUMDes, tanah kas desa.Sementara hasil aset yang dimaksud berupa tambahan perahu, pasar desa, tempat pemandian umum, jaringan irigasi.Swadaya, partisipasi dan gotong royong yang di maksud gotong royong merupakan kekuatan sendiri yang melibatkan peran serta masyarakat berupa tenaga, barang yang dinilai dengan uang.Pada pasal 11 Kelompok transfer terdiri atas jenis: (1) Dana Desa, Bagian dari Hasil Pajak Daerah Kabupaten/Kota dan Retribusi Daerah, Alokasi Dana Desa (ADD), Bantuan Keuangan dari APBD Provinsi, serta Bantuan Keuangan APBD
Kabupaten/Kota. (2) Bantuan Keuangan dari APBD Provinsi dan Kabupaten/Kota dapat bersifat umum dan khusus. (3) Bantuan Keuangan bersifat khusus sebagaimana dimaksud pada ayat (2) dikelola dalam APBDesa tetapi tidak diterapkan dalam ketentuan penggunaan paling sedikit $70 \%$ (tujuh puluh perseratus) dan paling banyak 30\% (tiga puluh perseratus). (4) Kelompok pendapatan lain-lain terdiri atas jenis: Hibah dan Sumbangan dari pihak ketiga yang tidak mengikat dan Lain-lain pendapatan Desa yang sah.

Pasal 12 permendagri nomor 113 tahun 2014 yang di maksud dengan belanja desa meliputi semua pengeluaran dari rekening desa yang merupakan kewajiban desa dalam 1 (satu) tahun anggaran yang tidak akan diperoleh pembayarannya kembali oleh desa. Artinya dana yang sudah di peroleh lalu dibelanjakan dan tidak mendapatkan ganti dari pengeluaran tersebut. Lebih lanjut dalam pasal yang sama dijelaskan belanja dipergunakan dalam rangka mendanai penyelenggaraan kewenangan Desa yang sudah menjadi kewajiban dan tanggungjawab perangkat desa. Klasifikasi belanja Desa terdiri atas kelompok: Penyelenggaraan Pemerintahan Desa, Pelaksanaan Pembangunan Desa, Pembinaan 
Kemasyarakatan Desa, PemberdayaanMasyarakat Desa dan Belanja Tak Terduga.

Pada bidang penyelenggaraan pemerintah Desa sebenarnya akunya sudah sesuai dengan permendagri nomor 113 tahun 2014 hanya saja pada sub akun tunjangan kepada Desa dan perangkat Desa ada tunjangan yang di berikan pada keluarga kepala desa dan keluarga perangkat Desa, dimana dalam permendagri tidak diatur tunjangan untuk keluarga. Pengeluaran ini menunjukan pada tataran pemerintah Desa tidak ada pengendalian internal Hery (2014) yang menjaga tingkat pengeluaran perangkat Desa Pada pasal 14 Jenis belanja pegawai dipergunakan untuk pengeluaran penghasilan tetap dan tunjangan bagi Kepala Desa dan Perangkat Desa serta tunjangan BPD.

Permendagri nomor 1132014 pasal 16 mengatur Belanja Modal digunakan untuk pengeluaran dalam rangka pembelian atau pengadaan barang atau bangunan yang nilai manfaatnya lebih dari 12 (dua belas) bulan.Artinya barang yang dibeli akan berumur lebih dari satu tahun, devinisi ini sesuai dengan pemaknaan asset jangka Panjang di dalam akuntansi Wida (2016)Pembelian atau pengadaan barang atau bangunan untuk kegiatan penyelenggaraan kewenangan desa. Dalam pembangunan Desa hanya diperbolehkan untuk penyelenggaraan kewenangan Desa dalam hal iniprioritas pemanfaatan dana desa yang berkaitan dengan pembangunan sarana dan prasarana desa berdasarkan keadaan dan potensi yang ada di desa, seiring tercapainya target RPJM dan RKP Desa tiap-tiap tahunnya (Vitasurya, 2016; Zhang \& Xu, (2016)

Pada bidang kemasyarakatan belanja yang dikeluarkan sangat sedikit sekali yaitu sebesar Rp. 20.259.000 apabila dibandingkan dengan pembangunan Desa yaitu sebesar Rp. 897.738.000.Jika dipersentase belanja desa bidang kemasyarakatan hanya $1 \%$ sementara bidang pembangunan sebesar $62 \%$.Pemberdayaan masyarakat menjadi hal penting dalam kebijakan ADD karena sejauh ini pembangunan yang telah ada memfokuskan kepada pembangunan fisik, seperti pengerasan jalan dan pembangun jembatan (Meutia dan Liliana 2017).

Bidang pemberdayaan masyarakat sebesar Rp. 67.500.000,- bidang ini lebih besar jika dibandingkan dengan pembinaan masyarakat yang hanya $1 \%$ dari pendapatan, sementara bidang 
pemberdayaan masyarakat memakan anggaran sebesar 5\%. Pemberdayaan masyarakat menjadi hal yang sangat penting dalam kehidupan berbangsa jika dibandingkan dengan pembangunan fisik (Meutia dan Liliana 2017).

\section{KESIMPULAN}

Selama satu tahun anggaran 2016 pemerintah Desa Sengon Bungel memperoleh pendapatan sebesar $\mathrm{Rp}$. 1.441.828.000 pendapatan tersebut berasal dari pendapatan asli Desa yang terdiri dari Lelang Bondo desa \& Ekx Bengkok Carik, Lelang Bengkok Petinggi 69.000.000 dan Perangkat Desa Rp. 144.200.000. Pendapatan Transfer sebesar Rp. 1.228.628.000 yang terdiri dari Bantuan Keuangan dana desa Rp. 662.586.000, Bagian dari Hasil Pajak dan Retribusi Daerah Kabupaten/Kota sebesar Rp. 32.542.000. Belanja Bantuan Keuangan Kepala desa ( ADD) Rp. 528.500.000, Bantuan KPMD Rp 5.000.000

Dari pendapatan tersebut di belanjakan sebesar $100 \%$ dengan nilai belanja yaitu Rp. 1.441.828.000. adapun belanja desa di pergunakan Bidang Penyelenggaraan Pemerintahan Desa sebesar $31 \%$ yaitu Rp. 453.340.000. Bidang Pelaksanaan
Pembangunan Desa sebesar $62 \%$ yaitu Rp 897.738.000. Bidang Pembinaan Kemsyarakatan sebesar $1 \%$ yaitu Rp. 20.250.000. Bidang Pemberdayaan Masyarakat

Sebesar 5\% yaitu Rp 67.500.000. Bidang Tak Terduga sebesar 0,2\% yaitu sebesar. 3.000.000. jika di bandingkan dengan permendari nomor113 Tahun 2014 penggunaan belanja Desa pada umumnya sudah tepat, hanya saya belanja bidang penyelenggaraan pemerintah Desa ada poit belanja yang belum di atur dalam permendagri Tahun 2014 yaitu pada akun tunjangan keluarga petinggi sebesar Rp. 144.200.000 dipergunakan untuk tunjangan keluarga petinggi dan perangkat Desa.

\section{DAFTAR PUSTAKA}

Undang-undang No. 6 Tahun 2014 Tentang Desa

Hanifah,S I dan Praptoyo S., 2015 "Akuntabilitas Dan Transparansi Pertanggungjawaban Anggaran Pendapatan Belanja Desa (APBDes)" Jurnal Ilmu \& Riset Akuntansi Vol. 4 No. 8, 1-15

Ismail Muhammad, dkk 2016 "Sistem Akuntansi Pengelolaan Dana 
Desa"Volume XIX No. 2, Agustus 2016 ISSN 1979 - 6471

Peraturan Pemerintah Nomor 43 Tahun 2014 Tentang Peraturan Pelaksanaan Undang-Undang Nomor 6 Tahun 2014 Tentang Desa

Indah Wahyuni., 2016 "Analisis Pelaksanaan Keuangan Desa Rowogempol Menurut Permendagri Nomor 113 Tahun 2014 (Studi Kasus Pada Desa Rowogempol Kecamatan Lekok Kabupaten Pasuruan Periode 2015” Digital Repository Universitas Jember.

Buletin Teknis Standar Akuntansi Pemerintah Nomor 14., 2013 “Akuntansi Kas" Komite Standar Akuntansi Pemerintah

Mahmudi 2010 "Manajemen Kinerja Sektor Publik "Penerbit: UPP STIM YKPN

Permendagri No. 113/2014 tentang pengelolaan keuangan Desa

Hery, 2014, "Pengendalian Akuntansi dan Manajemen”, Kencana, Jakarta

Wida, S. A. (2016). Akuntabilitas Pengelolaan Alokasi Dana Desa (ADD) di Desa-Desa Kecamatan Rogojampi Kabupaten Banyuwangi
Vitasurya, V. R. (2016). Local Wisdom for Sustainable Development of Rural Tourism, Case on Kalibiru and Lopati Village, Province of Daerah Istimewa Yogyakarta. Procedia Social and Behavioral Sciences, 216, 97-108. https:// doi.org/10.1016/j.sbspro.2015.12.0 14

Inten $\mathrm{M}$ dan Liliana Pengelolaan Keuangan Dana Desa Jurnal Akuntansi Multiparadigma JAMAL Volume 8 Nomor 2 Halaman 227-429 Malang, Agustus 2017 ISSN 2086-7603 eISSN 2089-5879 